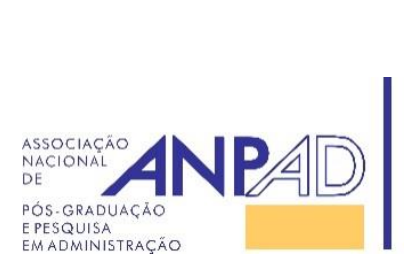
Disponível em
http://www.anpad.org.br/rac
RAC, Rio de Janeiro, v. 21, n. 4, art. 4,
pp. 500-523, Julho/Agosto, 2017
http://dx.doi.org/10.1590/1982-7849rac2017160187
(c)) EY

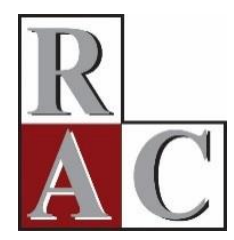

\title{
Dispositivo de Potterheads: Organização Pautada na Ordem do Cânone
}

Potterheads Dispositif: Organization Guided by the Order of the Canon

Flávia Zimmerle da Nóbrega Costa ${ }^{1}$ André Luiz Maranhão de Souza Leão ${ }^{1}$

Universidade Federal de Pernambuco ${ }^{1}$

Artigo recebido em 06.07.2016. Última versão recebida em 19.01.2017. Aprovado em 20.01.2017. Publicado online em 18.04.2017. 


\title{
Resumo
}

Os fãs da saga Harry Potter, conhecidos como potterheads, pertencem a uma geração que cresceu em um contexto denominado cultura da convergência. Organizam-se a partir de um produto midiático em um espaço social denominado fandom, por meio de um processo organizativo informal. Embasados no pensamento foucaultiano e na teoria organizacional, assumimos que processos organizativos podem ser analisados como um tipo de dispositivo e que este se estabelece por práticas. Com base nisso, desenvolvemos a seguinte questão investigativa: como as práticas dos potterheads evidenciam seu processo organizativo? A pesquisa se caracteriza como uma Análise de Discursos Foucaultiana, com base em práticas de potterheads observadas em mídias sociais. Como resultado, identificamos que o cânone deste universo literário e cinematográfico funciona como um corpo de saberes ordenado, cuja função disciplinar possibilita a organização de seus fãs, que se dá numa dinâmica de aderência e resistência ao mesmo. O estudo revela como um processo organizativo singular (vida organizada dos potterheads), vinculado a um cenário econômico de crescente importância (indústria do entretenimento), ilustra como um dispositivo opera na produção de espaços sociais e subjetividades, em meio a uma economia afetiva operada como uma tecnologia biopolítica.

Palavras-chave: potterheads; processo organizativo; cultura da convergência; dispositivo; Análise de Discurso Foucaultiana.

\begin{abstract}
Fans of the Harry Potter saga, known as Potterheads, belong to a generation that grew up in a context called convergence culture. They are organized based on a media product in a social space called fandom, through an informal organizational process. Grounded in Foucault's thinking and organizational theory, we assume that organizational processes can be analyzed as a kind of dispositif and that this is established by practices. Based on this, we developed the following investigative question: how do Potterhead practices demonstrate their organizational process? The research is characterized as a Foucauldian Discourse Analysis, based on practices of Potterheads observed in social media. We identified that the canon of this literary and cinematic universe works as an ordered body of knowledge, whose disciplinary function enables the organization of their fans, which occurs in a dynamic of adhesion and resistance to it. The study reveals how a singular organizational process (Potterheads' organized life), linked to an economic environment of increasing importance (the entertainment industry), illustrates how a dispositif operates in the production of social spaces and subjectivities, in the midst of an affective economy operated as a biopolitical technology.
\end{abstract}

Key words: potterheads; organizational process; convergence culture; dispositif; Foucauldian Discourse Analysis. 


\section{Introdução}

A saga Harry Potter conquistou uma legião de aficionados fãs, os potterheads, que, por meio desse universo, constroem seus mundos particulares e produzem valores e verdades. Como militantes convictos e produtores incorrigíveis, produzem conteúdos e agenciamentos políticos, instigando a solidariedade imediata e global da comunidade (Jenkins, 2009). Esse trabalho é feito em defesa de suas ideias/vontades, sejam elas causas sociais em que acreditam, contra ou a favor de princípios morais vigentes, ou ainda se opondo ao que consideram preconceitos e injustiças sociais. Para Jenkins (2009), é a partir desse envolvimento que a cultura da comunidade é produzida, orbitando o conteúdo da saga e moldando o ambiente interativo onde acontecem suas várias atividades.

Hoje, uma das atividades mais importantes dos fãs é a produção de novos conteúdos a partir dos produtos midiáticos (Jenkins, 2009). A produção cultural originada nas práticas dos potterheads, envolve afetividade, sociabilidade, agenciamento político e a produção de textos culturais. Em um caso de grande repercussão, os potterheads reivindicaram novas posturas da Warner Bros., a líder mundial em comercialização e distribuição de filmes longas metragens: em 2001, resistiram para manter seus perfis na internet utilizando o nome da marca, quando a empresa adquiriu e reivindicou o direito à propriedade de uso da mesma (Sewell, n.d.); outro exemplo pode estar no período entre 2010 e 2015, quando o grupo lutou pela certificação de origem dos chocolates comercializados no parque temático da Universal Orlando, justificando o alinhamento aos valores da saga (Rosenberg, 2015).

Harry Potter é considerado um produto midiático representativo de uma geração de fãs (Brown \& Patterson, 2009, 2010; Dendle, 2011; Hall, 2016). Os lançamentos sequenciados da saga literária e cinematográfica aconteceram com enorme sucesso ao longo de 14 anos. Além desses jovens terem crescido convivendo com tais lançamentos, o produto foi vastamente distribuído: a obra foi traduzida para mais de 60 idiomas e atingiu grande parte das famílias ocidentais (Archer, 2015), tornando-se um símbolo de uma geração e uma das mais robustas narrativas de mídia da atualidade (Brown \& Patterson, 2006).

Os potterheads ilustram o modo de vida de uma geração conhecida como millennials. Esses jovens, nascidos a partir da década de 1980, possuem estreita afinidade com ferramentas tecnológicas e um amplo domínio sobre elas (Chaves, 2012; McCorkindale, DiStaso, \& Sisco, 2013; Myers \& Sadaghiani, 2010). Apoiados nesses recursos tecnológicos, a geração millennials produz identidades e realidades, viabilizando sua vasta interatividade e o acesso imediato a informações (Moura, 2013). Exposta à cultura das mídias, a geração convive e naturalmente se envolve com os produtos da indústria cultural, de onde extraem subsídios para essas construções (Guschwan, 2012), produzindo novos modos de socialização, relação, escolha e consumo (Coelho \& Las Casas, 2013; McCorkindale et al., 2013).

Para Jenkins (2009), novas formas de relação se estabelecem entre comunidades de fãs, tecnologias e produtores midiáticos, constituindo o que ele denominou de cultura da convergência. Tal noção insere-se numa racionalidade política que se desenvolve a partir das novas tecnologias de informação e comunicação, que recebe muitos rótulos, a depender das lentes do pesquisador. Por exemplo, enquanto Jenkins (2009) a nomeia como economia afetiva, Brown e Patterson (2006) a batizaram de economia do entretenimento. A despeito de suas particularidades, os diferentes conceitos evidenciam uma profunda mudança no cenário, nos papéis e nas ações em um dos campos economicamente mais relevantes da atualidade: o das indústrias criativas. Essas transformações ainda estão sendo exploradas, mas possuem antepassados relevantes e consolidados nos estudos organizacionais, como as indústrias culturais, seus sistemas e a produção de cultura (Jones, Svejenova, \& Townley, 2016).

Fãs constituem hoje grupos expressivos e organizados, formados por relações de consumo. Analisar a esfera do consumo tornou-se relevante para a teoria organizacional, assim como o estudo das formas organizacionais alternativas despertou o interesse de estudiosos (Fontenelle, 2015; Rodgers, Petersen, \& Sanderson, 2016). O fandom é o espaço social que as sedia e propicia os intensivos diálogos entre fãs (Amaral, Souza, \& Monteiro, 2015; Guschwan, 2012), e é considerado por Jenkins (2009) uma 
comunidade cultural complexa, mantida pelo estilo particular de consumo e pela preferência cultural. Nesse espaço, a combinação de esforços individuais e colaborativos almeja a realização de propósitos coletivos. Seu processo organizativo legitima identidades e agências que participam da rede responsável por conduzir processos de valor nas indústrias criativas. Na medida em que atuam como cocriadores na concepção, na produção e na distribuição de produtos e serviços (Jones et al., 2016), fãs constituem subjetividades e desestabilizam as relações de poder (Pearson, 2010), não podendo mais ser observados como consumidores passivos (Jenkins, 2009).

O fandom pode ser entendido como um processo organizativo informal singular, que se estabelece e mantém por meio de um procedimento particular de gestão. Princípios de valor e condições de participação são regulados: o que é ser ou não fã, em que se deve acreditar e o que se deve defender, quais atividades são pertinentes a um fã, como se posicionar frente às críticas e aos estigmas sociais etc. Os temas são sempre lutas particulares que acontecem recorrentemente no interior desse tipo de comunidade e que se refletem nos demais espaços frequentados por esses consumidores. Como em qualquer espaço social, o fandom sofre a ação dos princípios estabelecidos pela racionalidade dominante e as práticas dos agentes subvertem a todo tempo as formas de poder institucionalizadas, [re]criando sua existência.

Nosso argumento parte do princípio de que organizar é, ao mesmo tempo, processo e estrutura (Clegg \& Bailey, 2008). Nesse sentido, consideramos que o fandom se caracteriza como uma espécie de vida organizada (Carrieri, 2014): um processo que nasceu da historicidade do cruzamento de várias forças, o qual acontece e é determinado pelo cenário capitalista e pelas várias relações de poder que o atravessam enquanto corpo social. A atuação de seus agentes na prática da gestão de sua existência interfere, ressignifica e modifica práticas institucionais de outras organizações e processos organizativos no cenário social e econômico em que estão inseridos, pois a gestão, segundo Carrieri (2014), é uma categoria política e um mecanismo de poder, na medida em que articula o saber-fazer com o saber-poder na promoção de agenciamentos.

Assim, seguindo o argumento de Carrieri (2014), analizar o fandom como um processo de gestão ordinária dessa vida organizada (uma descontinuidade) é pensar criticamente; é partir da desconstrução de conceitos, deslocando-se da racionalidade dominante. Partir de descontinuidades e desconstruir conceitos é próprio da abordagem pós-estruturalista (Souza, Petinelli-Souza, \& Silva, 2013).

Embasada na epistemologia pós-estruturalista foucaultiana, uma das vertentes críticas nos estudos organizacionais explora o processo organizativo (organizing) (Caldwell, 2007), assumindo uma postura ontológica politicamente oposta à visão metateórica de organização (Duarte \& Alcadipani, 2016). Entendendo-as como espaços políticos (Marshak \& Grant, 2008) resultantes de um contínuo organizar (Duarte \& Alcadipani, 2016), assumem a gestão como um espaço de disputas ininterruptas (Carrieri, Perdigão, \& Aguiar, 2014). O entendimento de poder foucaultiano nos embasa para fugir da totalização de representações. Seu pensamento transforma nossa compreensão acerca das estruturas sociais, do poder e dos sujeitos livres, pois, apesar de entendê-los como sendo historicamente condicionados, eles assumem sua posição em um sistema aberto e contingente (Foucault \& Deleuze, 1977).

Logo, organizar pode ser entendido como dispositivo. Com base no pensamento foucaultiano, Carrieri (2014) entende que processos organizativos podem ser analisados como um tipo de dispositivo e a gestão como uma ferramenta de poder, pois, sendo o poder relacional e, portanto, móvel, ele é disseminado por dispositivos. A organização é pautada em um corpo de saberes e no exercício de poderes, e a gestão ocupa um papel relevante nessa complexa rede em que relações de poder promovem relações de sujeição, fabricando sujeitos, sejam dóceis ou subversivos.

Para Foucault, o arranjo que resulta em processos singulares de veridição, subjetivação e objetivação, capaz de produzir sujeitos e objetos, constitui um dispositivo (Chignola, 2014). Assim, o poder é operado por dispositivos; estes, por sua vez, são formados por uma rede de forças de naturezas distintas, englobando a variação de elementos e direção dessas forças (Foucault, 2015). O dispositivo se estabelece por práticas. As práticas sociais cristalizam os discursos (Foucault, 2012), materializando e fazendo funcionar os efeitos de poder (Foucault, 2015). 
Considerar o fandom como vida organizada é entendê-lo como parte de um dispositivo, logo, ele torna-se capaz de revelar saberes por meio de poderes. Para tal, devemos partir das práticas de fãs em seu fandom em busca do entendimento de seu processo organizativo. Nesse sentido, questionamo-nos: Como as práticas dos potterheads evidenciam seu processo organizativo?

Como práticas de potterheads, referimo-nos às atividades coletivas desses fãs em seu fandom, ações que revelam a maneira como eles interagem como forma de produzir saberes por meio de suas produções relacionadas ao universo da saga. Assim, a questão de pesquisa elaborada busca revelar a rede de saberes que, operada por poderes, possibilita a efetivação do processo organizativo dos potterheads.

O trabalho se justifica, inicialmente, por se debruçar sobre um tipo de organização potencialmente reveladora da diversidade de modos de realização na vida social contemporânea (i.e., organização de fãs), que, por sua vez, tem sido pouquíssimo explorado pelas ciências sociais (Carrieri, 2014). De forma mais contundente, colocarmo-nos criticamente frente a esse fenômeno nos dá margem para pensar a relação entre organizações e vida organizada de uma forma alternativa: em vez de partir da busca de como as organizações e suas formas de gestão determinam a vida organizada, assumimos o tipo de organização em pauta como singular, assim tendo um valor específico inerente à sua capacidade de ilustrar novas formas de organização social na contemporaneidade.

Por outro lado, nos Estudos Organizacionais, as dinâmicas de poder e os processos de subjetivação do pensamento foucaultiano fundamentam uma linha dos estudos (Carrieri, 2014; Marshak \& Grant, 2008; Souza, Junquilho, Machado, \& Bianco, 2006), em que se posiciona essa pesquisa.

Revelar a dinâmica desse processo organizativo é indicar como opera e se constitui um dispositivo, uma ferramenta que, atrelada a outros dispositivos, operacionaliza a existência de um espaço social (fandom) e o agenciamento de sujeitos a partir dele (potterheads). Para Raffnsøe, GudmandHøyer e Thaning (2016), utilizar o dispositivo como ferramenta para a análise permite uma compreensão mais complexa da dinâmica organizativa, pois desvela e elucida a ação das mais sutis formas de poder que atravessam os processos organizativos. Apesar do pensamento foucaultiano ser considerado relevante para a área, o potencial dessa ferramenta foi muito pouco explorado nos estudos organizacionais (Raffnsøe, Gudmand-Høyer, \& Thaning, 2016); esperamos que aqui se localize a contribuição dessa pesquisa.

\section{O Dispositivo em Michel Foucault}

Como força, o poder não é algo que pertence a alguém, mas algo que se exerce (Foucault, 2013). O poder é relacional, microfísico, e mantém com o saber uma relação de apoio e reforço mútuos, pois sua operacionalização se dá por meio dele, gerando novos saberes. Sendo uma relação entre forças, o exercício de poder sempre produz resistência, estando nessa relação a própria dinâmica do que é de caráter social (Foucault, 2014). A resistência não se constitui como uma oposição ao poder nem se pretende como uma sobreposição ao mesmo. O poder e a resistência são coconstitutivos (Caughlan, 2005; Collinson, 2006; Hardt \& Thomas, 2014; Raffnsøe et al., 2016); sua dinâmica relacional pode promover as mudanças organizacionais, já que o poder é produtivo (Thomas, Sargent, \& Hardy, 2011) e a resistência é transgressiva (Raffnsøe et al., 2016).

Para o filósofo, o poder se estabelece e corta o espaço social porque se apoia em dispositivos. Cada rede relacional é formada por elementos heterogêneos (discursivos e não discursivos) e possibilitam a criação de mecanismos que sustentam o exercício do saber-poder e estabelecem matizes normativas de condutas para o corpo social (Foucault, 2013). Segundo o autor, o social não discursivo constitui a instituição, ou seja, são comportamentos equipados de certa coerção que são aprendidos e, portanto, naturalmente praticados (revelando-se discursivos) (Foucault, 2014). 
Assim, as estratégias de poder funcionam por se amparar ou se tornar sujeições, sendo que o dispositivo torna-se um regime de ordem para o social. No dispositivo, portanto, está a condição para o estabelecimento das verdades, os modos de pertencimento e as ações de sujeitos; o dispositivo engloba todos "os elementos que intervieram em uma racionalidade" (Foucault, 2014, p. 246). Chignola (2014) comenta que o dispositivo foucaultiano é analisado por Deleuze como a forma pela qual a multiplicidade se realiza segundo a característica de uma singularidade. A cartografia plural de forças forma um diagrama como uma multiplicidade no tempo-espaço, extensivo a todo o social e formado por alianças flexíveis e transversais (Deleuze, 2005), estabelecendo as relações poder-saber e poder-resistência que se dão em seu interior.

Desse modo, o dispositivo é essencial para o exercício da disciplina, pois possibilita a criação do aparelho que faz ver e funcionar os efeitos de poder (Foucault, 2015). A noção de dispositivo como um regime de forças disciplinar foi construída na obra Vigiar e Punir, quando Foucault trabalhou o Panóptico como um dispositivo. Deleuze (2005) analisa que houve um aprofundamento nesse estudo da dimensão do visível, lembra a importância da diferença de natureza que existe entre o saber (forma) e o poder (força), das capturas e imanência mútuas e do primado de um (poder) sobre o outro (saber). Isso porque, para Foucault (2015), o dispositivo se constitui e mantém graças a um processo de sobre determinação funcional, em que os efeitos produzidos pelo poder sofrem rearticulação constante para seu ajustamento e para o permanente preenchimento estratégico.

Deleuze (2005) sinaliza o entendimento de Foucault de que vivemos continuamente presos a dispositivos, mas que, em seu interior, atuamos assinalando o que já não somos e elaborando o que queremos ser. No pensamento foucaultiano, os modos de se reconhecer e dirigir em determinada relação de forças é ser sujeito. Assim, ser sujeito envolve sujeitar-se a, mas sujeitar-se não significa deixar-se dominar, uma vez que em termos foucaultianos dominação não é poder. Ou seja, sujeito, para Foucault, é "uma linha de chegada de uma tensão constituinte que utiliza uma força ... e olha para o Eu como um alvo de um arqueiro" (Chignola, 2014, p. 10).

Por sua vez, quando Foucault (2008) analisou as práticas do neoliberalismo e a consolidação do sistema capitalista, apontou como característico do poder na sociedade moderna o ajuste que se estabeleceu entre a população enquanto corpo vivente e os processos econômicos. Segundo ele, desde esse período, a vida tornou-se objeto de controle do saber e das intervenções do poder, e esse sistema delineou o surgimento de uma forma-sujeito considerada como máquina produtiva de fluxos de renda. Para o filósofo, o poder sobre a vida é entendido como biopoder, e toda a tecnologia de poder operada sobre a vida e os corpos da população é biopolítica. Assim, o biopoder associado à biopolítica tornou hegemônico o modelo capitalista; nesse os agentes acontecem sob a lógica produtivo-econômica do capital.

\section{A Era da Convergência Midiática e a Geração Millenials}

Houve um tempo em que gostar de ficções e lê-las em demasia já foi entendido como uma qualidade depreciativa. Dom Quixote, sucesso editorial lançado em 1605, retratou o medo social de se afastar da racionalidade iluminista e deixar-se dominar pelo mundo da fantasia, estabelecendo inovações na relação entre linguagem e mundo (Dias, 2016). Hoje, muito se discute acerca do fã e de seu comportamento: suas atitudes tipicamente geracionais, suas lutas por meio do consumo, seu trabalho não remunerado etc. Contudo, as particularidades que costumam chamar mais a atenção ainda são sua afeição, seu apego e sua fidelidade ao cânone, tido como excessivos.

Por sua vez, cada vez mais numerosos e atuantes, os fãs mostram-se orgulhosos de sua condição (Amaral et al., 2015). Como consumidores particulares, esses agentes se mobilizam, produzem e influenciam comportamentos por meio de experiências de consumo (Redden \& Steiner, 2000; Thorne \& Bruner, 2006), devendo ser analisados como sujeitos potencialmente transgressores de vários saberes tradicionais (Jenkins, 2009). 
Por sua condição própria de acesso à vasta plataforma de opções de entretenimento, os fãs fazem parte de uma geração estreitamente envolvida com a cultura pop (Chaves, 2012), e habituada a solucionar problemas utilizando os meios digitais (McCorkindale et al., 2013; Myers \& Sadaghiani, 2010), apoiando-se no conteúdo dos produtos para produzir seus mundos (Jenkins, 2009). Consumidores digitais naturalmente geram grandes quantidades de conteúdo juntamente a uma massa de informações sobre si mesmos, e esses dados nutrem o sistema capitalista (Charitsis, 2016).

Talvez por isso, para alguns autores, o ambiente digital naturalizou a cultura do trabalho voluntário e colaborativo (Charitsis, 2016). O consumidor produtor assume naturalmente parte dos trabalhos de divulgação e promoção de produtos e serviços que antes eram resultados apenas de serviços profissionais contratados pelas organizações. Entretanto, agem com o mesmo afinco quando é o caso de fazerem críticas em situações de insatisfação com a forma como as organizações lidam com os produtos de que são fãs. Sendo assim, seu trabalho tanto pode aumentar e manter o interesse público por produtos por mais tempo, como levá-los a um desempenho mercadológico insatisfatório, o que tem implicações, positivas ou negativas, na lucratividade das organizações (Matias, Silveira, \& Brandão, 2015; McCorkindale et al., 2013; Myers \& Sadaghiani, 2010).

Considerado uma atividade prazerosa e divertida, esse trabalho é comumente entendido como dispensado de remuneração. Contudo, embora não remunerado financeiramente, tem um enorme valor para constituição do fã como sujeito social. Jenkins (2009) analisa como a racionalidade proveniente desse trabalho adquiriu os moldes de uma economia, pois a capacidade de compartilhar interesses, desenvolver redes, criar cultura e institucionalizar a comunidade, implica que se desenvolvam, para além do ativismo político, os laços constituintes de uma inteligência afetiva vital para manter o envolvimento e a própria atividade acontecendo. Evidentemente, a indústria reconhece o potencial valor financeiro de tal trabalho e estabelece contato com os agentes para distribuir suas informações (Chin, 2014).

Entretanto, o estigma que carrega o trabalho gratuito provém também de uma perspectiva de pensamento hegemônico, fundamentada historicamente: o trabalho só é legitimado pelo pagamento e adquire status pelo valor que lhe é atribuído. Chertkovskaya e Loacker (2016) analisam que a subsunção da vida ao trabalho foi fundamental para a reprodução material e simbólica do sistema capitalista, mas entendem que as esferas da produção e do consumo convivem entrelaçadas, e, em sua interdependência, são responsáveis por organizar condições da vida social. O reconhecimento do consumo como um meio de subsistência (Redd, 2016) parece ter afetado as subjetividades moldadas na forma-trabalho convencional, ficando cada vez mais difícil identificar e separar trabalho e consumo da própria vida (Hoedemaekers, 2016).

As práticas de consumo que contribuem com o processo de produção são estudadas como trabalho no consumo, ou consumo produtivo (Chertkovskaya \& Loacker, 2016; Fontenelle, 2015). A gestão do processo organizativo dos fandoms pauta-se num trabalho afetivo de fãs, constituinte de identidades e subjetividades no consumo. No trabalho realizado nos fandoms, os fãs ganham confiança e habilidades para lidar com os problemas de seu cotidiano (Jenkins, 2009). Ao gerir esse modo organizativo produzindo cultura, os fãs constroem entendimentos que lhes dão suporte para ocupar os papéis sociais no cotidiano dos demais espaços sociais que habitam (Korobkova \& Black, 2014). Nessa vida contemporânea organizada, cabe aos fãs gerir esse espaço e manterem-se nele. Carrieri (2014) elucida que os processos organizativos ordinários atuam interligados em rede com outros dispositivos sociais, e que desvelar os saberes que são aí produzidos permite pensar criticamente acerca dos inúmeros modos de realização no espaço social.

O apoio no ferramental analítico do dispositivo possibilita revelar as circunstâncias específicas sob as quais uma organização se realiza, bem como suas dinâmicas próprias; essa analítica busca exatamente esclarecer como objetos, práticas e experiências tidas como verdadeiras surgiram pela interação entre dispositivos (Raffnsøe et al., 2016). Os autores avaliam que, para realizar uma análise a partir de um dispositivo deve-se, por exemplo, questionar dicotomias, confrontar concepções históricas ou periodizações generalistas e não considerar que um dispositivo possa ser subordinado ou redutível a outro. Segundo os autores, no original, o termo dispositif significa a descrição de um arranjo desenvolvido para um propósito específico e projetado para ter um efeito imediato, sendo caracterizado 
por uma predisposição ou plano segundo o qual elementos heterogêneos estão se organizando em determinado aparelho social, pois sua natureza é relacional.

\section{Gestão Ordinária: Um Dispositivo Particular}

Apenas na década de 1980, os estudos organizacionais brasileiros investiram com mais força nas análises críticas focadas no poder e nas mudanças organizacionais (Marshak \& Grant, 2008), interesse que abriu espaço para o apoio de pesquisadores na obra de Michel Foucault, que, por sua vez, fortaleceu pesquisas centradas em práticas e processos organizativos (Caldwell, 2007). Essa linha de pensamento pós-estruturalista (vide Souza, 2012) entende as organizações como espaços políticos de lutas, em que os jogos de poder assumem uma importância central (Marshak \& Grant, 2008). Nesse entendimento, o campo organizacional é político (Souza et al., 2006), e a gestão é um mecanismo para a ação do poder (Carrieri, 2014). Além disso, organizações não possuem fronteiras definidas, existindo como resultantes do seu contínuo processo organizativo (Duarte \& Alcadipani, 2016).

Assim, visando questionar a instrumentalização e descontruir a retórica gerencial, o apoio no pensamento foucaultiano desloca o olhar do pesquisador de contextos legitimados. Se Afastar-se da visão hegemônica de organização é, portanto, analisar outras experiências organizativas, fugindo da instrumentalização dos jogos do saber-poder (Carrieri et al., 2014). Entendendo que organizar é uma realização contínua (Cooren, Kuhn, Cornelissen, \& Clark, 2011), estudos buscam perceber como processos organizativos constroem significados e identidades (Oliveira \& Cavedon, 2013), como reproduzem estruturas, como as confrontam (Barros \& Carrieri, 2015) e transformam (Sampaio, Fortunato, \& Bastos, 2013). Tal visão foca o cotidiano dos sujeitos (organização caracterizada como vida organizada), os saberes [des]qualificados de cientificidade satisfatória (Carrieri, 2014), e o tempo presente para resgatar sua historicidade, interessando-se por descontinuidades e dando voz aos excluídos (Carrieri, Souza, \& Aguiar, 2014).

Entender que a relação pode-saber de modo interdependente e não dicotômico potencializa o pensamento crítico, pois não sujeita este pensamento a hierarquias e ordens discursivas (Geppert, Becker-Ritterspach, \& Mudambi, 2016). Do mesmo modo, a relação poder-resistência é entendida como uma relação coconstitutiva em que o processo é visto como transgressivo e dinamizador da ordem social (Caughlan, 2005; Collinson, 2006; Courpasson, Dany, \& Martí, 2016; Hardt \& Thomas, 2014; Raffnsøe et al., 2016; Thomas et al., 2011). Essa linha de pensamento entende o conceito de gestão também num sentido amplo, não reducionista do termo (uso formal, apenas aplicado em processos de organizações tradicionais). Gestão engloba toda ação efetuada por sujeitos para gerir a vida cotidiana, sendo atravessada por outras construções, uma vez que os indivíduos sofrem múltiplas interferências no ambiente interno e externo às organizações, estando o cotidiano imbricado por questões políticas. Assim, sendo categorias políticas, modos de gestão ganham forma estreitamente inter-relacionadas nos espaços sociais (Carrieri, 2014).

Nesse sentido, Carrieri (2014) vem desenvolvendo o conceito de Gestão Ordinária, e a entende como aquela "desenvolvida no cotidiano dos negócios, da vida organizada" (p. 25). Para o autor, o cotidiano é uma produção que surge a partir das práticas dos indivíduos em seu dia a dia e a gestão, como um mecanismo de poder, é uma categoria central do universo organizacional capaz de articular todas as outras categorias. $\mathrm{O}$ autor afirma que as relações sociais estão em constante jogo para a gestão do cotidiano, sendo esse espaço constituído pelos modos de fazer, criar e/ou desviar de formas hegemônicas. Ele denomina de vida organizada as múltiplas relações que se dão para a construção e a reprodução da vida em sociedade. Considera a Vida organizada como uma vida arranjada de uma dada forma (capitalista), sendo sua construção histórica e determinada. Abraçar tal conceito lhe permite partir de uma concepção desnaturalizada de sociedade e de organização.

Assim, o pensamento foucaultiano possibilita a análise de fenômenos em gestão por meio da interdependência constitutiva da relação saber-poder (produtora de verdades, sujeitos e da própria 
realidade), sendo o poder veiculado por dispositivos (Carrieri, 2014; Souza et al., 2005). A partir desse pensamento, Carrieri (2014) analisa que processos organizativos funcionam como um tipo de dispositivo, tornando sua gestão particular uma ferramenta para o exercício de poder.

Com base nessas argumentações, assumimos o fandom como uma instância de vida organizada, cortada por uma rede de forças e estabelecida pela ação de dispositivos que lhe propiciam um regime de ordem baseado na estruturação de saberes. Assim, a gestão desse espaço aconteceria pela dinâmica do exercício do poder e da resistência, que rearticula seus efeitos e os ajusta para seu constante preenchimento estratégico com novos saberes. Ou seja, entender o fandom como organização e fãs como consumidores produtores, possibilita investigar como agentes e dinâmicas transformam produtos, padrões de consumo e processos de gestão num ambiente caracterizado por novas tensões entre consumidores e ofertantes de produtos e serviços (Jones et al., 2016).

\section{Procedimentos Metodológicos}

A decisão por certo grau de indução na nossa pesquisa nos manteve receptivos a descobertas no campo empírico (Leão, Mello, \& Vieira, 2009; Paiva, Leão, \& Mello, 2011). Nossas categorias analíticas foram produzidas no decorrer de uma análise sistemática efetuada no processo de coleta e volta aos dados, efetuado em paralelo às leituras da fundamentação teórica que embasou este estudo.

A análise de discursos é uma abordagem já estabelecida em disciplinas de ciências sociais (Feltham-King \& Macleod, 2016; Greckhamer \& Cilesiz, 2014). Aqui empregamos a Análise de Discursos Foucaultiana. Esta revela e descreve as regras que regulam os discursos, entendendo como elas constroem os objetos de que tratam (Feltham-King \& Macleod, 2016; Souza, Bianco, \& Silva, 2016). Tal ordem reflete as relações que cercam uma experiência em um tempo e um espaço, desvelando saberes (Foucault, 2012). Adamson (2016) esclarece que a não existência de uma metodologia para essa analítica está em conformidade com os pressupostos do pensamento foucaultiano. Assim, considerando que a analítica foucaultiana se refere a um método filosófico e que a utilizamos como um método de pesquisa social, adotamos as categorias discursivas trabalhadas por Michel Foucault na obra Arqueologia do Saber. Então, procedemos primeiro à identificação dos enunciados, seguido das funções que possuem no contexto discursivo e das regras que essas relações indicam obedecer, as quais, finalmente, apontam para a formação discursiva.

Para Foucault (2012), como os enunciados são um feixe de relações, precisam ser pesquisados a partir de posições de sujeitos em frações de saberes, em estratos discursivos associados ou em concretudes indicativas de regularidades que marquem descontinuidades. As funções indicam as operações estratégicas que os saberes assumem no cenário discursivo, portanto, são reveladas a partir de uma operação de decifração. Para essa etapa, pistas elucidativas surgem da relação entre si estabelecida pelos enunciados. Da mesma forma que enunciados estão ligados a suas funções, as regras existem como base das formações, regulando os atos discursivos. Assim, para Foucault (2012), a regra informa a condição a que estão submetidos os elementos na rede discursiva e a formação aparece como uma regularidade "entre objetos, tipos de enunciação, os conceitos, as escolhas temáticas" (p. 43). O autor (Foucault, 2012) analisa que as regras surgem a partir de quatro critérios: objetos, conceitos, modalidades e estratégias.

Ao identificarmos a relação dos enunciados entre si, dois tipos de relações apareceram: as relações que chamamos de síncronas, e que se referem aos enunciados que se apoiam e explicam mutuamente, e as relações incidentes, que indicam enunciados que explicam outros. Essa etapa nos forneceu fundamento para elucidar as funções enunciativas. Na sequência, para cada relação enunciado-função identificada em nossa análise, procedemos aos questionamentos: (a) Como cada prática constitui um objeto, de que objeto se tratou?; (b) O que se diz sobre o objeto, compreendendo que o conceito surge de regularidades?; (c) A partir de que lugar e de que modo o objeto foi tratado, tendo em vista a modalidade discursiva adotada?; (d) Qual a finalidade de se referir ao objeto por meio de um ethos, que 
estratégia se revela nesse intuito? A consistência dessa relação apontou a regularidade que compôs a formação discursiva em nossa analítica.

Foucault (2012) nomina de arquivo o conjunto de dados coletado. O arquivo pode equivaler, de certa forma, ao conceito de corpus em pesquisa qualitativa. Sua diferença está no fato de que o arquivo comporta o saber: seu conjunto não pode ser pré-determinado, mas sua completude delimita o objeto e apura a questão de pesquisa. Já para o corpus, esse conjunto de materiais é finito, determinado a priori e arbitrariamente pelo pesquisador (Bauer \& Aarts, 2010).

Em conformidade com nosso problema de pesquisa, nosso arquivo foi formado com base nas práticas de potterheads. São as práticas que institucionalizam os discursos no meio social e, portanto, potencialmente revelam saberes (Foucault, 2012). Nesse processo, identificamos um conjunto de vintes ações que se apresentaram habituais no cotidiano do fandom (Vide Tabela 1). Para defini-las, sistematizamos na coleta documentos virtuais contendo interações de fãs no fandom em variadas mídias sociais. Essas interações revelaram que os potterheads mantinham práticas habituais em seu relacionamento cotidiano. À medida em que as práticas foram delineadas, elas tornaram-se um critério para organização do arquivo, orientando a seleção de novos documentos. Seguindo Foucault (2012), a construção do arquivo faz parte da analítica. Nessa etapa, refina-se a questão investigativa e delimita-se o objeto.

Tabela 1

\section{Práticas de Potterheads}

\begin{tabular}{|c|c|}
\hline Práticas & Descrição \\
\hline Acusar poser. & $\begin{array}{l}\text { Trata da denúncia de pessoas que se fazem passar por fãs (i.e., posers), } \\
\text { estabelecendo alteridade e evidenciando uma subjetividade desestabilizadora de } \\
\text { saberes legitimados. }\end{array}$ \\
\hline Adorar o universo. & $\begin{array}{l}\text { Engloba as declarações públicas de amor dos potterheads ao universo de Harry } \\
\text { Potter, evidenciando a legitimação de suas construções culturais e ideológicas. }\end{array}$ \\
\hline Colecionar merchandises. & $\begin{array}{l}\text { Trata do conjunto de produtos licenciados da marca (i.e., merchandises) adquirido } \\
\text { pelos fãs, bem como de suas pesquisas, indicações e exibições no fandom; são } \\
\text { ações políticas de educação, exercício de poder e construção de valores. }\end{array}$ \\
\hline Comparar livros a filmes. & $\begin{array}{l}\text { Envolve a indicação de peculiaridades da saga não contempladas nos filmes } \\
\text { objetivando comprovar o domínio de saberes do fã e indicar o que se deve fazer } \\
\text { para ocupar essa posição. }\end{array}$ \\
\hline Depor acerca do universo. & $\begin{array}{l}\text { Abrange a exposição detalhada de vivências/experiências do fã com o cânone, } \\
\text { visando exaltar sua afinidade com este e com a cultura do fandom, e também } \\
\text { informando o papel do fã. }\end{array}$ \\
\hline $\begin{array}{l}\text { Difundir o conteúdo da } \\
\text { saga. }\end{array}$ & $\begin{array}{l}\text { Trata da difusão dos saberes do cânone com intuito de demonstrar domínio de } \\
\text { conhecimento, legitimar a prática e educar novos fãs acerca de seu papel para a } \\
\text { cultura do fandom. }\end{array}$ \\
\hline $\begin{array}{l}\text { Participar da seleção de } \\
\text { casas. }\end{array}$ & $\begin{array}{l}\text { Envolve todo o processo compulsório de demarcação de elementos identitários do } \\
\text { fã para participar do fandom, efetuado por meio dos saberes do cânone. As relações } \\
\text { de resistência aqui produzidas se tornam estratégias de poder. }\end{array}$ \\
\hline $\begin{array}{l}\text { Participar de encontro de } \\
\text { fãs. }\end{array}$ & $\begin{array}{l}\text { Consiste em tomar parte dos encontros de fãs, trocar experiências, bem como } \\
\text { difundir as mesmas no fandom, atualizando e fortalecendo essa cultura. }\end{array}$ \\
\hline $\begin{array}{l}\text { Participar de estreias de } \\
\text { filmes e lançamentos de } \\
\text { livros. }\end{array}$ & $\begin{array}{l}\text { Envolve a participação e a partilha das experiências dos lançamentos de filmes e de } \\
\text { livros da saga Harry Potter, reconstruindo valores e fortalecendo a cultura. }\end{array}$ \\
\hline
\end{tabular}




\section{Tabela 1 (continuação)}

\begin{tabular}{|c|c|}
\hline Práticas & Descrição \\
\hline $\begin{array}{l}\text { Reeditar/remixar } \\
\text { conteúdos culturais. }\end{array}$ & $\begin{array}{l}\text { Diz respeito a toda produção de fãs efetuada a partir de elementos da saga, tais } \\
\text { como filmes, músicas e posts, seja pela junção com outros produtos culturais, ou } \\
\text { com eventos sociopolíticos e culturais, reconstruindo verdades e valores. }\end{array}$ \\
\hline $\begin{array}{l}\text { Tietar os artistas dos } \\
\text { filmes e a autora da saga. }\end{array}$ & $\begin{array}{l}\text { Trata dos modos de evidenciar a admiração e a dedicação do fã pela autora e pelos } \\
\text { atores da saga, tal como relatando o empenho e o esforço efetuado para se } \\
\text { aproximar dos mesmos; a ação educa e constitui a realidade subjetiva do espaço. }\end{array}$ \\
\hline Produzir fan fictions. & $\begin{array}{l}\text { Abrange a produção de narrativas textuais do fã a partir da história original, } \\
\text { ressignificando o cânone. }\end{array}$ \\
\hline Produzir fan arts. & $\begin{array}{l}\text { Envolve a produção de desenhos e colagens a partir dos elementos originais da } \\
\text { saga Harry Potter, ressignificando o cânone. }\end{array}$ \\
\hline $\begin{array}{l}\text { Escrever para meios } \\
\text { digitais especializados. }\end{array}$ & $\begin{array}{l}\text { Versa sobre o abastecimento das mídias digitais com conteúdos atualizados e de } \\
\text { interesse do fandom, produzindo cultura e provendo condições para amplas } \\
\text { discussões. }\end{array}$ \\
\hline Jogar quadribol. & $\begin{array}{l}\text { Trata da prática dessa atividade esportiva, bem como das experiências de fãs a } \\
\text { partir dela, divulgando, mas também ressignificando relações com o universo. }\end{array}$ \\
\hline Duelar. & $\begin{array}{l}\text { Se refere à participação de fãs em atividades competitivas, como a disputa do } \\
\text { domínio de saberes com fãs de outras sagas, divulgando e também ressignificando } \\
\text { relações com o universo. }\end{array}$ \\
\hline $\begin{array}{l}\text { Degustar feijõezinhos de } \\
\text { todos os sabores. }\end{array}$ & $\begin{array}{l}\text { Diz respeito à experiência do fã no desafio de provar os feijõezinhos - doces com } \\
\text { sabores por vezes estranhos - tal como trama ficcional, divulgando e } \\
\text { ressignificando o universo. }\end{array}$ \\
\hline Fazer tatuagens. & $\begin{array}{l}\text { Envolve a experiência do fã em marcar o corpo com signos do universo e de } \\
\text { partilhar esse processo no fandom, gerando saberes e poderes. }\end{array}$ \\
\hline Fazer cosplay. & $\begin{array}{l}\text { Envolve o processo de encenação que o fã faz dos personagens da saga, uma } \\
\text { experiência que ressignifica os sentidos do universo. }\end{array}$ \\
\hline Rever filmes e reler livros. & $\begin{array}{l}\text { Versa sobre a prática habitual no fandom de rever os filmes e reler os livros da } \\
\text { saga; é parte da educação do fã, possibilita o domínio dos saberes e a construção de } \\
\text { cultura. }\end{array}$ \\
\hline
\end{tabular}

O arquivo foi formado por 593 documentos, 313 na língua inglesa e 280 na língua portuguesa, uma vez que esse espaço não é delimitado por fronteiras geográficas. Desse conjunto, 67 documentos eram vídeos e foram coletados na plataforma YouTube; os demais documentos foram no formato de imagens e textos, e coletados nos canais Facebook, Twitter, Tumblr, Instagram, Snapchat, Ask.fm, Yahoo Answer, Share Question, Qzone e Whisper, blogs e websites. O critério estabelecido para a seleção desses documentos foi que contivessem a fala de potterheads e que contemplassem alguma de suas práticas rotineiras. Para a seleção dessas mídias, bem como para uma contribuição validativa no reconhecimento das práticas, lançamos mão das informações de dois potterheads. Sua função foi puramente consultiva uma vez se tratarem de nativos desse universo, não se configurando como sujeitos participantes da pesquisa. O arquivo foi assim composto por dados multifociais, fazendo jus à complexidade do objeto (Flick, 2009).

Em todo o processo buscamos atender aos critérios de qualidade da pesquisa qualitativa. O rigor em pesquisas qualitativas é validado por critérios próprios de validade e confiabilidade, que devem ser definidos durante a elaboração do projeto da pesquisa e implementados com rigor durante processo (Elo et al., 2014; Morse, Barrett, Mayan, Olson \& Spiers, 2002). Os diferentes tipos de dados coletados, por meio de diferentes fontes, serviram como uma forma de atribuir uma representatividade do corpus de pesquisa. Uma triangulação dos dados se deu por uma dupla camada analítica: os dados foram primeiramente analisados por um dos autores e, posteriormente, tal procedimento analítico foi validado pelo outro. Por sua vez, exercitamos a reflexividade por meio dos constantes questionamentos, no 
processo analítico, acerca das relações entre evidências empíricas e o corpo teórico. Por fim, apesar do espaço limitado para a elaboração do artigo, buscamos apresentar uma descrição rica e detalhada da pesquisa (Paiva et al., 2011).

\section{Análise dos Resultados}

A formação enunciativa identificada é apresentada a partir de suas regras, de forma articulada com os conceitos teóricos e embasada em dados empíricos. Antes, porém, apresentamos seus elementos constituintes.

\section{Elementos da formação discursiva}

Nossa análise revelou 12 enunciados, 12 funções e 2 regras de formação. Os enunciados (Tabela 2) foram nomeados por meio de proposições afirmativas, no intuito de esclarecer seu sentido no cenário discursivo. A Tabela 3 descreve as funções enunciativas. Para nomeá-las, empregamos verbos no infinitivo, esclarecendo a ação dos enunciados a elas vinculados. Na Tabela 4, os critérios de regra: objetos, conceitos e modalidades foram nomeados por meio de substantivos, e as estratégias foram descritas por meio de locuções substantivas.

Tabela 2

\section{Enunciados}

\begin{tabular}{|c|c|c|}
\hline \multicolumn{2}{|c|}{ Enunciados } & \multirow{2}{*}{$\begin{array}{l}\text { Descrição } \\
\text { Diz respeito à apropriação dos saberes do cânone por fãs como uma } \\
\text { fonte de verdade e, portanto, orientadora de conduta. }\end{array}$} \\
\hline E01 & $\begin{array}{l}\text { Potterheads aplicam saberes do } \\
\text { universo em suas vidas. }\end{array}$ & \\
\hline E02 & $\begin{array}{l}\text { Potterheads expressam gratidão } \\
\text { ao cânone. }\end{array}$ & $\begin{array}{l}\text { Engloba os modos de demonstração de agradecimento ao cânone pelo } \\
\text { valor deste em suas vidas, um suporte (re)negociado nessas trocas. }\end{array}$ \\
\hline E03 & $\begin{array}{l}\text { Potterheads não resistem às } \\
\text { práticas do fandom. }\end{array}$ & $\begin{array}{l}\text { Envolve os efeitos do arrebatamento ocasionado pela vontade de } \\
\text { participar de práticas do fandom, o que, naturalmente, acomete o fã, } \\
\text { graças à força de seu vínculo afetivo. }\end{array}$ \\
\hline E04 & $\begin{array}{l}\text { Potterheads zelam pela } \\
\text { autenticidade do cânone. }\end{array}$ & $\begin{array}{l}\text { Engloba as ações de fãs com vistas a proteger a originalidade do } \\
\text { conteúdo do cânone. }\end{array}$ \\
\hline E05 & $\begin{array}{l}\text { Potterheads colecionam itens } \\
\text { relacionados à saga. }\end{array}$ & $\begin{array}{l}\text { Trata da prática habitual de "caçar" e adquirir produtos licenciados da } \\
\text { marca, apresentando-os com orgulho no fandom e indicando o cuidado } \\
\text { dedicado à sua manutenção. }\end{array}$ \\
\hline E06 & $\begin{array}{l}\text { Potterheads reverenciam o } \\
\text { cânone. }\end{array}$ & $\begin{array}{l}\text { Envolve as práticas que respeitam o corpo de saberes do cânone; } \\
\text { objetivam manter a posição do fã no fandom, fortalecendo-o e } \\
\text { oportunizando ao mesmo atualizar os valores do universo. }\end{array}$ \\
\hline E07 & $\begin{array}{l}\text { Potterheads estabelecem } \\
\text { vínculos no fandom. }\end{array}$ & $\begin{array}{l}\text { Refere-se aos laços mútuos que se estabelecem entre fãs (amparo, } \\
\text { influências e coerções), preservando e atualizando a cultura. }\end{array}$ \\
\hline E08 & $\begin{array}{l}\text { Potterheads usam os saberes do } \\
\text { cânone para endossar suas } \\
\text { convicções. }\end{array}$ & $\begin{array}{l}\text { Trata da apropriação de conteúdos do cânone por fãs para o endosso } \\
\text { de crenças do fandom. }\end{array}$ \\
\hline E09 & $\begin{array}{l}\text { Potterheads usam os saberes do } \\
\text { cânone para questionar suas } \\
\text { convicções. }\end{array}$ & $\begin{array}{l}\text { Diz respeito à apropriação de conteúdos do cânone por fãs para } \\
\text { questionar crenças do fandom. }\end{array}$ \\
\hline
\end{tabular}




\section{Tabela 2 (continuação)}

\begin{tabular}{lll}
\hline Enunciados & Descrição \\
\hline E10 & $\begin{array}{l}\text { Potterheads estabelecem } \\
\text { identificações com integrantes } \\
\text { dofandom. }\end{array}$ & $\begin{array}{l}\text { Envolve o reconhecimento de afinidades em termos de gosto, } \\
\text { assumpção de posturas e entendimento de mundo; prática que } \\
\text { estabelece a identidade de fã. }\end{array}$ \\
\hline E11 & $\begin{array}{l}\text { Potterheads burlam as } \\
\text { determinações do cânone. }\end{array}$ & $\begin{array}{l}\text { Trata das resistências de fãs em relação às normas e aos procedimentos } \\
\text { oriundos dos saberes do cânone. }\end{array}$ \\
\hline E12 & $\begin{array}{l}\text { Potterheads se acautelam em } \\
\text { relação à lei de direitos } \\
\text { autorais. }\end{array}$ & $\begin{array}{l}\text { Diz respeito aos cuidados adotados pelos fãs em suas produções, } \\
\text { visando driblar/minimizar os efeitos de possíveis punições previstas na } \\
\text { lei de direitos autorais, por usarem, sem autorização, os símbolos do } \\
\text { cânone. }\end{array}$ \\
\hline
\end{tabular}

Tabela 3

\section{Funções Enunciativas}

\begin{tabular}{|c|c|c|}
\hline \multicolumn{2}{|c|}{ Funções } & \multirow{2}{*}{$\begin{array}{l}\text { Descrição } \\
\text { Evidenciar mudanças pessoais adquiridas pelos fãs a partir da } \\
\text { relação com o cânone. }\end{array}$} \\
\hline F01 & $\begin{array}{l}\text { Demonstrar transformações pessoais } \\
\text { dos fãs. }\end{array}$ & \\
\hline F02 & $\begin{array}{l}\text { Reconhecer benefícios da relação com } \\
\text { o cânone. }\end{array}$ & Admitir os ganhos de vida a partir da relação com o cânone. \\
\hline F03 & $\begin{array}{l}\text { Satisfazer vontade de práticas do } \\
\text { fandom. }\end{array}$ & $\begin{array}{l}\text { Saciar a vontade impetuosa de participar de atividades do } \\
\text { fandom. }\end{array}$ \\
\hline F04 & Perpetuar o universo de Harry Potter. & Dar continuidade ao universo mantendo-o funcionando. \\
\hline F05 & Enaltecer o cânone. & Atribuir e propagar a grandeza do cânone para a vida de fãs. \\
\hline F06 & Prover condição de fã. & $\begin{array}{l}\text { Nutrir/disseminar as qualidades determinantes do fã de Harry } \\
\text { Potter. }\end{array}$ \\
\hline F07 & Resguardar a autenticidade do cânone. & Proteger a originalidade das características do cânone. \\
\hline F08 & Demonstrar confiança no cânone. & $\begin{array}{l}\text { Comprovar para os demais fãs a certeza depositada nos saberes } \\
\text { canônicos. }\end{array}$ \\
\hline F09 & Valorar o universo de Harry Potter. & Outorgar méritos ao universo fantástico. \\
\hline F10 & $\begin{array}{l}\text { Evidenciar identificações com o } \\
\text { universo de Harry Potter. }\end{array}$ & Demonstrar conformidade de fãs com o universo. \\
\hline F11 & $\begin{array}{l}\text { Esclarecer características de fãs no } \\
\text { fandom. }\end{array}$ & Explicar peculiaridades de fãs no fandom. \\
\hline F12 & Resguardar condição de produtor. & $\begin{array}{l}\text { Assegurar o reconhecimento do valor para a manutenção do } \\
\text { trabalho de produtor cultural a partir da saga. }\end{array}$ \\
\hline
\end{tabular}


Tabela 4

\section{Critérios de Regras}

\begin{tabular}{ll}
\hline Objetos & \\
\hline $\begin{array}{l}\text { Ordem (O1) } \\
\text { Resistência (O2) }\end{array}$ & $\begin{array}{l}\text { Diz respeita às práticas habituais de fãs que endossam os saberes do cânone. } \\
\text { Diz respeito à incompatibilidade de ideias entre fãs e as determinações do cânone. }\end{array}$ \\
\hline Conceitos & \\
\hline Regularidade (C1) & Evidencia a condição de frequência com que ocorrem as atividades de fãs. \\
Adequação (C2) & Refere-se à luta pelo ajustamento do vínculo do fã com o fandom. \\
\hline Modalidades & Revela uma posição firme a respeito de crenças e valores. \\
\hline Convicção (M1) & Diz respeito à inventividade utilizada para a adaptação a situações. \\
Criatividade (M2) & \\
\hline Estratégias & Demonstra a existência de práticas rotineiras e intensivas. \\
\hline $\begin{array}{l}\text { Força do hábito (E1) } \\
\text { Tática de luta (E2) }\end{array}$ & Revela a arte de coordenar ações para obter condições favoráveis. \\
\hline
\end{tabular}

As regras se relacionaram com os critérios da seguinte forma: (a) A prática organizativa dos potterheads adere aos saberes do cânone, e teve, por objeto: ordem; por conceito: regularidade; por modalidade: convicção; e por estratégia: força do hábito; (b) A prática organizativa dos potterheads resiste aos saberes do cânone, teve, por objeto: resistência; por conceito: adequação, por modalidade: criatividade, e, por estratégia: tática de luta.

\section{A ordem do cânone é o aparelho disciplinar do processo organizativo dos potterheads}

A formação discursiva apresentou-se ligada a duas regras de formação que surgiram da relação entre 12 enunciados e 12 funções enunciativas (vide Figura 1). A relação entre si estabelecida pelos enunciados evidenciou suas funções a partir da existência de dois grupos de significação no contexto discursivo: relações poder-saber e relações poder-resistência.

No grupo relativo às relações saber-poder em que dez enunciados dessa formação de algum modo se relacionaram, indicando a centralidade do enunciado de número 6, que sofreu incidência dos demais enunciados que o explicam. Entre esses enunciados, surgiu uma relação incidente: o enunciado 8 explicou o 7 e o 10, uma vez que os saberes do cânone são apropriados para a construção dos argumentos que visam estabelecer identificações e vínculos no fandom. Esse grupo de enunciados indica os modos pelos quais os potterheads produzem uma ordem a partir de um corpo de saberes (cânone). Na Figura 1 , abaixo do grupo dos enunciados, as relações incidentes estão representadas por setas e as relações síncronas representadas por linhas. 
A ordem do cânone é o aparelho disciplinar do processo organizativo dos potterheads

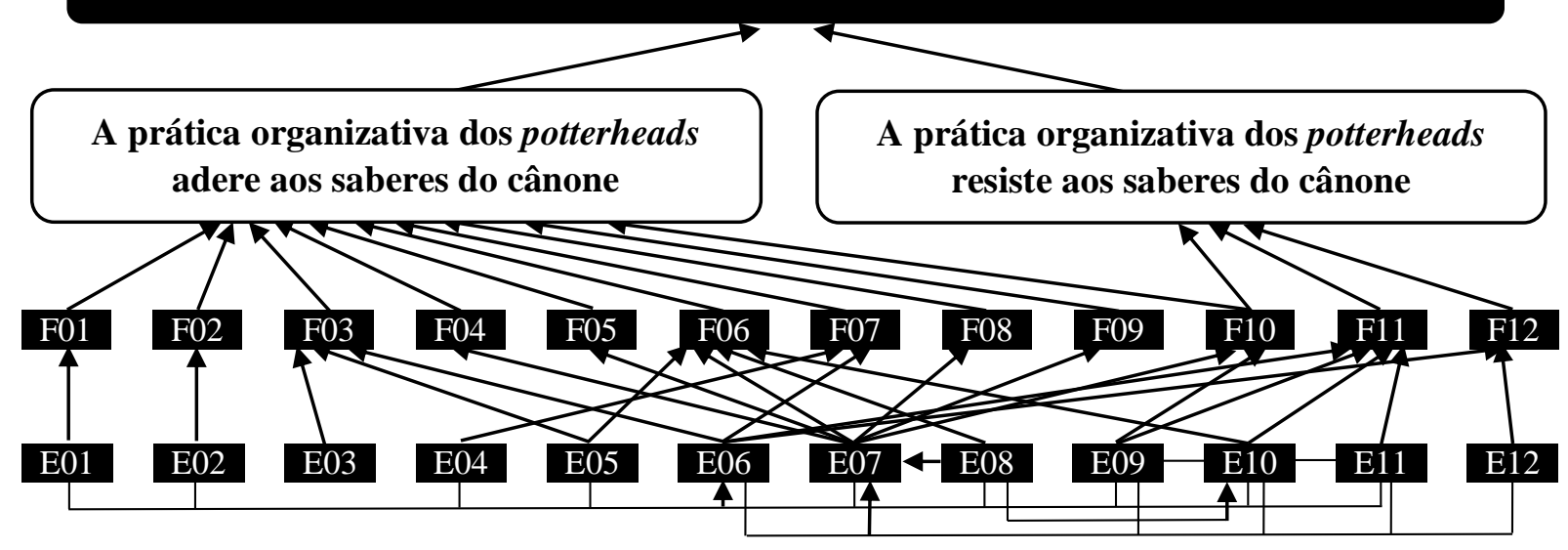

Figura 1. Mapa das Relações da Formação Discursiva

O segundo grupo refere-se às relações poder-resistência, sendo composto pelas relações entre cinco enunciados e três funções. Nesse grupo, surgiu a centralidade do enunciado 7, que sofreu incidência dos enunciados $6,9,10,11$ e 12, indicando que é por meio de relações persuasivas que os potterheads organizam sua resistência. As relações de resistência se constituem sempre apoiadas no estabelecimento de vínculos, por meio da troca de conselhos e de apoio mútuo, e de ações persuasivas que são cuidadosamente argumentadas, inclusive sendo pautadas em identificações estabelecidas entre fãs. Nesse grupo, revelou-se também uma relação síncrona: os enunciados 9,10 e 11 se explicam mutuamente, pois, para burlar e/ou questionar saberes do cânone, potterheads estabelecem identificações com outros integrantes, produzindo argumentos que justificam sua ação.

Esse segundo grupo de enunciados indica as formas pelas quais os potterheads desestabilizam e atualizam sua ordem de existência. Assim, o cânone (corpo de saberes) assume uma função disciplinar que possibilita a organização dos potterheads, pois funciona como um dispositivo e as práticas dos potterheads aderem e resistem a esse corpo de saberes numa dinâmica constitutiva de sua organização. A ordem de determinado espaço social é produzida por relações sociais que, segundo Carrieri (2014), estão em constante atividade para gestão do cotidiano. Por sua vez, a gestão revelou-se uma prática política que acontece pela disciplina dos corpos, pois os potterheads precisam adotar para si, como valor, o corpo de saberes do cânone, podendo assim regular por meio dele a sua conduta e a do outro, produzindo cultura. Como afirmam Marshak e Grant (2008), a organização é um espaço político que se efetiva pelo contínuo organizar. Assim é por meio dispositivo (cânone) que todo um exercício de disciplina funciona (Foucault, 2014), pois, em sua singularidade, o processo organizativo desenvolve o ferramental, que fez materializar os efeitos de poder, revelando a natureza relacional do dispositivo (Raffnsøe et al., 2016).

Nesse sentido, as práticas dos potterheads revelaram atividades rotineiras ao cotidiano do fandom, essenciais para os que querem se inserir ou legitimar na posição de fãs. Agamben esclarece: o dispositivo funciona a partir da institucionalização adquirida por regras e rituais praticados (Chignola, 2014). O modo como esse corpo de saberes ordena a vida dos potterheads apareceu nas duas regras dessa formação: de um lado a institucionalização das práticas de ordem e de outro a sua desestabilização, que promove os ajustes e a dinamicidade dos sentidos ali acordados, pois as relações de resistência são constituintes do espaço que molda corpos, objetos e práticas (Hardt \& Thomas, 2014).

Por sua vez, as sociabilidades promovidas por meio desse dispositivo, levam para essas relações a lógica do capital. Para Chertkovskaya e Loacker (2016), o estabelecimento do capitalismo pósindustrial ou pós-fordista fez o mercado emergir como um princípio social regulativo central e, em um ambiente centrado no mercado e na produtividade, as ações dos sujeitos se voltam para a criação de valor. Charitsis (2016) analisa que práticas cotidianas do consumidor da era digital costumam produzir valor econômico para as organizações, o que, acredita, vem transformando a própria vida em 
mercadoria. A organização dos potterheads produz os sujeitos promovendo o crescimento da indústria, endossando o sistema capitalista e revelando como a lógica de troca/lucro tornou-se uma lógica imanente às práticas sociais. A condição nos leva a entender que a ordem dos potterheads é biopolítica no sentido foucaultiano (Foucault, 2014). Essa condição é transversal a todo corpo discursivo do arquivo, pois a existência biopolítica é própria dos modos de vida contemporâneos. E, como são relações saber-poder que nascem nesse meio e estabelecem verdades, as mesmas ditam a forma de pertencimento, de convivência e também a condição de agência dos sujeitos. Por outro lado, relações de poder suscitam as relações de resistência, relações essas que reconstroem a cultura e acomodam os modos de pertencimento, pois a resistência é parte das relações de poder (Caughlan, 2005; Collinson, 2006; Hardt \& Thomas, 2014; Raffnsøe et al., 2016) e os sujeitos são participantes ativos nesse processo (Välikangas \& Seeck, 2011).

\section{A prática organizativa dos potterheads adere aos saberes do cânone}

A relação entre as funções e os enunciados que elucidaram essa regra, revelaram que crenças, valores e verdades (a mola mestra da cultura) compõem a ordem dessa organização. As convicções são reforçadas ou reconstruídas na dinâmica das práticas dadas a partir dessa ordem, cuja regularidade aos poucos se torna hábito, conduzindo a conduta dos potterheads.

A relação entre saberes e funções indicou a reverência ao cânone como uma relação saber-poder central para a organização dos potterheads. Na relação de respeito a esse corpo de saberes, revelaramse práticas estabelecedoras da ordem desse espaço social, tais como as promessas de amor e continuidade, e o hábito de partilhar informações, sentimentos e emoções. A gratidão, o apoio em saberes do cânone e a dedicação às várias práticas, como colecionar, reler os livros e rever a saga cinematográfica, constroem e reforçam os valores partilhados no fandom. A ordem envolve ainda a participação do potterhead no processo de seleção de casas, prática que o designará nesse espaço social pela assumpção de um perfil identitário.

Como o fandom se divide e funciona conforme a narrativa, o fã se filia ao mesmo participando do processo de seleção de casas. Na ficção, a escola de magia de Hogwarts se divide em quatro casas: Grifinória, Sonserina, Corvinal e Lufa-Lufa. Cada casa possui características particulares que definem seus membros. Assim, participar da seleção é a primeira prova que enfrenta o fã no fandom, é definitiva e só se passa por ela uma vez, tal como o é na trama ficcional. Apesar de existirem muitos testes na internet, a seleção oficial é promovida pelo Pottermore (website criado pela autora). O processo marca o fã, pois lhe atribui características e lhe propicia mais que uma família: uma identidade perante o fandom.

Em geral, essa determinação não agrada ao fã, que se enxerga pertencendo à outra casa. A insatisfação é gerada por tratar-se de características pessoais pelas quais o participante será conhecido; envolver identificações e afinidades. A prática propiciou inúmeros exemplos que podem ilustrar os feixes de relações dessa regra, conforme o trecho de fala:

Acho muita covardia a pessoa não aceitar a casa que o Chapéu te colocou (já que ele realmente NUNCA erra) e deu ouvidos a Harry simplesmente pq não era $100 \%$ dele que estava naquele banquinho, uma boa parte de Voldemort falava mais alto, fazendo o Chapéu querer colocá-lo na Sonserina, porém Harry Potter sempre foi um Grifinoriano (disso não se tem dúvida) e quando o Chapéu te coloca em uma casa (ainda mais vc tendo respondido tudo com sinceridade É REALMENTE AQUELA CASA QUE VOCÊ PERTENCE) lembrando que as vezes nem mesmo você não sabe o potencial que tem, e grande coisa ela (Nilsen Silva) ter gosto por leituras e querer cair na Corvinal, Hermione tem esse gosto também mais do que ninguém e está na Grifinória, então aceite onde vc está ou exclua a sua conta. O CHAPÉU NUNCA ERRA e se vc foi para Lufa-Lufa é lá que você pertence ACEITE (Guilherme, 2012).

Apesar do desagrado com o resultado do processo, inscrever-se para a seleção de casas denota atestar e renovar a confiança depositada no cânone, é assentir ser ordenado por ele e ser definido por um 
de seus modelos identitários. Participar do fandom é trabalhar pela legitimidade desses valores: prover condição de fã é função de Potterheads reverenciam o cânone.

O argumento de que o chapéu "NUNCA erra" visa persuadir o outro insatisfeito, pois isso é parte do esforço para manter a integridade da ordem: Potterheads estabelecem vínculos no fandom para prover condição de fã. É preciso justificar utilizando elementos da própria narrativa, pois Potterheads usam saberes do cânone para endossar suas convicções visando prover condição de fã. Ser honesto com o cânone o levará para a casa certa, ainda que o fã não se conheça o suficiente para saber disso: Potterheads estabelecem vínculos no fandom para Demonstrar confiança no cânone. O fã conquista seu direito de fala ao mostrar que conhece o enredo. Essa é uma das características mais valoradas no fandom: o verdadeiro fã conhece o universo: Potterheads estabelecem vínculos no fandom para Evidenciar identificações com o universo de Harry Potter.

Apesar da seleção de casas ser um processo muito significativo, reverenciar o cânone é bem mais amplo que isso. O hábito de reler os livros e colecionar itens da saga é trabalhar para manter a ordem e a própria condição de fã; isso é dar provas de dedicação (as atividades exigem tempo e dinheiro), e envolvimento (isso dá credibilidade a ele no fandom). São ainda exercícios sistemáticos a proteção dos valores e conteúdos originais, e a demonstração pública de gratidão ao cânone. Para muitos jovens, a experiência rica e duradoura fez amigos, promoveu diversão, emoção e um norte para suas condutas. Assim, o conjunto de ideias, práticas e valores que formam a cultura foi fortemente construído por meio das atividades de ordem; o hábito incorporado no tempo produziu a repetição material capaz de manter essa forma organizativa. Como a cultura do fandom é gerida em torno do dispositivo, ele se estabelece como ordem e, por meio da relação poder-saber, indica o que se faz e como se faz, e o que é certo ou não.

O feixe de relação que origina essa regra revelou relações saber-poder legitimadas e constituintes da ordem, uma externalidade definida a priori, em que cabe aos potterheads apenas se inscrever. A adesão voluntária dos potterheads aos saberes do cânone indica como um dispositivo funciona na construção de estruturas sociais: rituais e regras se tornam saberes institucionalizados, portanto, internalizados - para Agamben, autopercepção e autoconsciência (Chignola, 2014), e o exercício da disciplina é aplicado primeiramente em si mesmo, depois na conduta do outro. Essa técnica de poder é chamada biopoder, pois, segundo Foucault (2015), sua eficiência está em agir sobre a vida promovendo ao mesmo tempo: disciplina, uma anátomo-política do corpo que orienta o indivíduo na conquista da vida produtiva, e docilização dos corpos, um adestramento que promove a adesão voluntária. Assim, o cânone revelou-se um tipo de dispositivo, e aderir aos saberes do mesmo é se inscrever na sua ordem, é sujeitar-se a para gerir e legitimar essa ordem.

\section{A prática organizativa dos potterheads resiste aos saberes do cânone}

A relação entre os cinco enunciados e três funções revelou que foi estabelecendo vínculos e produzindo argumentos de qualidade (embasados nos saberes do cânone) que os potterheads conquistaram o espaço para abalar a estabilidade dos poderes instituídos, e assim questionar saberes, burlar determinações, estabelecer identificações e continuar produzindo. A relação incidente no enunciado 7, bem como a relação síncrona entre os enunciados são explicativas dessa condição (vide Figura 1). Ao suscitar o reconhecimento de igualdades de ideias entre fãs nas diversas atividades e se apropriar dos saberes do próprio cânone, estabeleceu-se a oportunidade para apontar inconsistências nos saberes instituídos. As funções que conduzem a regra dizem respeito às finalidades da resistência, uma busca de adequação às condições que lhes foram impostas. Ilustramos o poder-resistência com o trecho de fala a seguir: 
O Pottermore é mesmo um site lindo e fantástico, e a proposta dele de interação entre fãs de todo o mundo por meio de um jogo-enciclopédia é sensacional. O problema é que eu acho que ele fugiu um pouco do discurso que tanto aprendemos na série sobre ter a chance de escolher. Quando fiz a seleção pela primeira vez, fui parar na Lufa-Lufa, casa dos que são pacientes, leais, justos e que não têm medo da dor. Fiquei chateada logo de cara e parei de jogar. Eu queria Corvinal. Minha sede de conhecimento, meu amor aos livros e minha paixão por escrever falavam mais alto. Eu sou medrosa e intolerante. Podem perguntar para quem me conhece, eles vão confirmar. Sou a Rainha da Impaciência. Eu tinha respondido o teste com toda a sinceridade do mundo, mas ele não atingiu às minhas expectativas e me mandou para um lugar ao qual eu achava não pertencer. E aí? (Guilherme, 2012).

O fã se apropria da moral do conteúdo da saga para questionar a atitude do chapéu e esclarecer porque suas características não correspondem às do resultado da seleção: Potterheads usam saberes do cânone para questionar suas convicções visando Esclarecer características de fãs no fandom. Ao iniciar a fala elogiando o cânone, o fã busca validar a construção de seu argumento e conquistar solidariedade política: Potterheads estabelecem identificações com integrantes do fandom para Esclarecer características de fãs no fandom.

Quando o fã utiliza saberes do cânone para questionar sua incoerência em termos morais desestabilizando o poder, ele produz estratégias de dessujeição, e essa já é uma estratégia de poder, pois o poder é produtivo quando sua relação com a resistência é coconstitutiva (Caughlan, 2005; Collinson, 2006; Hardt \& Thomas, 2014; Raffnsøe et al., 2016). Ao resistir aos saberes do cânone, ele elaborou a razão que pauta seu argumento, e sua questão visa promover um debate: "E aí?". Apontando a incoerência moral da prática do cânone, o fã incita os outros a mudarem as regras, pois, se o Pottermore não faz o que diz, os fãs podem desobedecê-lo. Assim, Potterheads estabelecem vínculos no fandom para esclarecer características de fãs no fandom.

Primeiramente vimos se estabelecer um processo de ordem, pois existimos presos a dispositivos (Chignola, 2014). Mas a resistência mostrou-se um agenciamento, movendo-se do caráter ético para uma força política (Deleuze, 2005); o fã refletiu sobre a moralidade do cânone, abalou a estabilidade da sujeição e produziu agenciamentos. Querer para si uma ligação com o cânone adequada, ainda que queira essa ligação, diz respeito a uma experiência de si no exercício da liberdade (Foucault, 2013). O agente usou a força para dobrar a força, criou, abalando verdades e produzindo subjetividades. Ao discordar da ordem: Potterheads burlam as determinações do cânone para esclarecer característica de fãs no fandom.

A produtividade estabelecida na relação de completude poder-resistência (Foucault, 2013) revelou-se fortemente vinculada à produção de fics (prática de reescrever as narrativas), hoje uma das ações mais relevantes no fandom e uma das formas mais utilizadas para mantê-lo vivo, trazendo a pauta a lei dos direitos autorais. Os argumentos criados para manter tal hábito por vezes perpassam pela lógica econômica: em geral, no contexto discursivo, o fã argumenta que livros servem para inspirar sua criatividade e que os autores deveriam se sentir lisonjeados por eles se interessarem por continuar suas histórias, afinal, isso promove o sucesso das vendas.

A criação do argumento é uma inversão (criação) pautada na ordem de funcionamento do mercado. Como afirma Holanda (2010), a racionalidade dominante produz ativamente o princípio de organização produtiva e social do mercado capitalista, impondo essa ordem aos modos organizativos. Foucault (2008) analisa que desde o neoliberalismo se governa para o mercado e não por causa dele, e que esse sistema delineou o surgimento de uma forma-sujeito considerada como uma máquina produtiva. Para o filósofo, o ajuste estabelecido entre a população enquanto corpo vivente e os processos econômicos é característico do poder moderno (disciplinar) e produtor da biopolítica.

Da mesma forma que a resistência desestabiliza o poder, seu potencial criativo é recorrentemente sequestrado por esse mesmo poder. Assim, a manutenção do fandom se revela como resultado de um processo de gestão que vai configurando e transformando o processo organizativo no decorrer da luta política pelo poder, pois o procedimento organizativo institucionaliza as práticas (Clegg \& Bailey, 
2008). Resistir aos saberes do cânone é produzir, é constituir subjetividades, pois a resistência é pura criação, produz as estratégias de dessujeição, desnuda as brechas do poder e possibilita a dinamização do espaço relacional (Foucault, 2015). Por meio da resistência aos saberes do cânone, apesar de historicamente condicionados, potterheads são sujeitos em um sistema aberto e contingente.

\section{Considerações Finais}

Por meio da Análise de Discursos Foucaultiana buscamos desvelar como as práticas dos potterheads evidenciam seu processo organizativo. A formação discursiva identificada revelou que a ordem do cânone é o aparelho disciplinar do processo organizativo dos potterheads. O cânone (um corpo de saberes de ordem) funciona como um aparelho disciplinar (dispositivo) que atua sobre o processo organizativo dos potterheads, possibilitando sua existência. As duas regras dessa formação indicaram como as práticas dos potterheads aderem a essa ordem e resistem à mesma e, nessa dinâmica, produzem sua organização. Várias práticas endossaram esse corpo de saberes, constituindo-o como uma ordem disciplinar, mas, à medida em que essa conforma o espaço social, a resistência se exerce, desestabilizando o poder.

Potterheads aderem à ordem do cânone enquanto corpo de saberes, e é por meio dele que a gestão desse espaço social opera em um exercício de disciplina, fazendo funcionar efeitos de poder aplicados à conduta daqueles. Num nível mais amplo, vemos como essa disciplina pauta um biopoder que age sobre a conduta tanto de si mesmo quanto sobre a do outro, regendo e mantendo o modo organizativo. Assim, mais do que apenas fãs de um dado produto cultural, potterheads vinculam-se ao universo literário como um corpo de saberes, logo, sob o efeito de seu poder.

Mas nossos achados revelaram que potterheads recorrentemente também resistem à ordem do cânone, subvertendo as formas de poder institucionalizadas, atualizando as relações de poder-saber e recriando sua existência. Para tanto, potterheads se pautam nesse mesmo corpo de saberes para produzir seus argumentos, influenciar condutas e reinventar a ordem. A construção desses argumentos é políticoafetiva e, por isso, capaz de produzir solidariedade para com quem foge às regras. Assim, mesmo sendo historicamente condicionados e sofrendo ação dos princípios da racionalidade dominante, potterheads abalam a estabilidade das sujeições, ajustam sentidos compartilhados e produzem agenciamentos.

É por meio de um processo de gestão reconstruído cotidianamente que os potterheads atualizam sua vida organizada. Eles constituem sua subjetividade ao sujeitarem-se ao cânone, num processo dinâmico entre adesão e resistência a esse corpo de saberes, típico das relações de poder e a seus efeitos, conforme nos ensina Michel Foucault. Então, é essa dinâmica de adesão e resistência aos saberes do cânone o que assegura o modo de vida organizada e o próprio trabalho dos potterheads.

A racionalidade do trabalho dos potterheads parece constituir o que Jenkins (2009) denominou de economia afetiva. Como a gestão ordinária que observamos em sua vida organizada é operada em meio a um mecanismo de poder revelada por uma tecnologia operada sobre a vida, afirmamos se tratar de um biopoder. Assim, concluímos que a economia afetiva em pauta é operada como uma tecnologia biopolítica no âmbito da vida organizada do fandom.

Como limitação do estudo, enxergamos que algumas informações importantes podem ter sido perdidas no tempo, uma vez que esses espaços sociais estão sempre em mudança: perfis são fechados, meios entram em desuso, mídias apagam as postagens em poucas horas etc. Contudo, para minimizar essa condição, buscamos efetuar a coleta nas mais variadas mídias sociais. Tendo em vista que as informações dos fandoms são sempre replicadas por vários meios, entendemos que essa limitação não prejudicou a nossa pesquisa.

A contribuição do trabalho para os Estudos Organizacionais está em desvelar como um processo organizativo singular (vida organizada dos potterheads), vinculado a um cenário econômico de crescente importância (indústria do entretenimento) ilustra como um dispositivo opera na produção de 
espaços sociais e subjetividades. Apesar de o dispositivo ser uma concepção-chave no pensamento de Michel Foucault, e seu pensamento ter se consagrado por promover avanços nas pesquisas organizacionais, o potencial dessa ferramenta foi muito pouco explorado na área (Raffnsøe et al., 2016). Evidentemente não se trata de uma busca de generalização deste conhecimento, mas, como diria Foucault (2012), de uma tentativa de libertar saberes locais normalmente sujeitados ao domínio das ciências conforme estas se estabeleceram na modernidade.

Por outro lado, entendemos ainda que nossa contribuição avance na proposta de sistematização da Análise de Discurso Foucaultiana, uma vez que o filósofo francês a apresentou muito mais como princípios de sua analítica arqueológica do que como um procedimento propriamente dito, o que, obviamente, tem a ver com o fato de se tratar de um método filosófico, enquanto aqui o adotamos como método de investigação em pesquisa social.

\section{Agradecimentos}

O projeto de pesquisa que deu origem a este trabalho foi realizado com o apoio do Conselho Nacional de Desenvolvimento Científico e Tecnológico (CNPq), processo n ${ }^{\circ}$ 306363/2015-1.

\section{Referências}

Adamson, M. (2016). Postfeminism, neoliberalism and a 'successfully' balanced femininity in celebrity CEO autobiographies [Special Issue]. Gender, Work \& Organization, 24(3), 213-327. http://dx.doi.org/10.1111/gwao.12167

Amaral, A., Souza, R. V., \& Monteiro, C. (2015). "De westeros no \#vemprarua à shippagem do beijo gay na TV brasileira". Ativismo de fãs: conceitos, resistências e práticas na cultura digital [Versão eletrônica], Galáxia, (29), 141-154. Recuperado de http://www.scielo.br/pdf/gal/n29/1982-2553gal-29-0141.pdf. http://dx.doi.org/10.1590/1982-25542015120250

Archer, D. (2015). Harry Potter and control: an inherent power narrative in the Wizarding World. Conversations, 2(1), 1-18.

Barros, A., \& Carrieri, A. P. (2015). O cotidiano e a história: construindo novos olhares na Administração. Revista de Administração de Empresas, 55(2), 151-161. http://dx.doi.org/10.1590/S0034-759020150205

Bauer, M., \& Aarts, B. (2010). A construção do corpus: um princípio para a coleta de dados qualitativos. In M. Bauer \& G. Gaskel (Eds.), Pesquisa qualitativa com texto, imagem e som: um manual prático (pp. 39-63). Petropolis: Vozes.

Brown, S., \& Patterson, A. (2006). You're a wizard, Harry! Consumer response to the Harry Potter phenomenon. Advances in Consumer Research, 33, 155-160.

Brown, S., \& Patterson, A. (2009). Harry Potter and the service-dominant logic of marketing: a cautionary tale. Journal of Marketing Management, 25(5/6), 519-533. http://dx.doi.org/10.1362/026725709X461830

Brown, S., \& Patterson, A. (2010). Selling stories: Harry Potter and the marketing plot. Psychology \& Marketing, 27(6), 541-556. http://dx.doi.org/10.1002/mar.20343

Caldwell, R. (2007). Agency and change: re-evaluating Foucault's legacy. Organization, 14(6), 769791. http://dx.doi.org/10.1177/1350508407082262 
Carrieri, A. P. (2014) As gestões e as sociedades. Farol - Revistas de Estudos Organizacionais e Sociedade, 1(1), 18-57.

Carrieri, A. P., Perdigão, D. A., \& Aguiar, A. R. C. (2014). A gestão ordinária dos pequenos negócios: outro olhar sobre a gestão em estudos organizacionais. Revista de Administração, 49(4), 698-713. http://dx.doi.org/10.5700/rausp1178

Carrieri, A. P., Souza, E. M. S., \& Aguiar, A. R. C. (2014). Trabalho, violência e sexualidade: estudo de lésbicas, travestis e transexuais. Revista de Administração Contemporânea, 18(1), 78-95. Recuperado de http://www.scielo.br/pdf/rac/v18n1/a06v18n1.pdf. http://dx.doi.org/10.1590/S1415-65552014000100006

Caughlan, S. (2005). Considering pastoral power: a commentary on Aaron Schutz's "Rethinking domination and resistance: challenging postmodernism". Educational Researcher, 34(2), 14-16. http://dx.doi.org/10.3102/0013189X034002014

Charitsis, V. (2016). Prosuming (the) self. Ephemera: Theory \& Politics in Organization, 16(3), 37-59.

Chaves, S. N. (2012). História da ciência através do cinema: dispositivo pedagógico na formação de professores de ciências. Alexandria Revista de Educação em Ciência e Tecnologia, 5(2), 83-93.

Chertkovskaya, E., \& Loacker, B. (2016). Work and consumption: entangled. Ephemera: Theory \& Politics in Organization, 16(3), 1-20.

Chignola, S. (2014). Sobre o dispositivo: Foucault, Agamben, Deleuze. Cadernos IHU Ideias, 12(214), 3-17.

Chin, B. (2014). Sherlockology and Galactica.tv: fan sites as gifts or exploited labor? Transformative Works and Cultures, (15). http://dx.doi.org/10.3983/twc.2014.0513

Clegg, S. R., \& Bailey, J. R. (2008). Introduction. In S. R. Clegg \& J. R. Bailey (Orgs.), International Encyclopedia of Organization Studies (pp. XIIII-XIVIII). California: SAGE Publication.

Coelho, D., \& Las Casas, A. (2013). A percepção dos consumidores da geração Y na aquisição de produtos tecnológicos (computadores) no ponto de venda. FACEF Pesquisa: Desenvolvimento e Gestão, 16(1), 83-96.

Collinson, D. (2006). Rethinking followership: a post-structuralist analysis of follower identities. The Leadership Quarterly, 17(2), 179-189. http://dx.doi.org/10.1016/j.leaqua.2005.12.005

Cooren, F., Kuhn, T., Cornelissen, J. P., \& Clark, T. (2011). Communication, organizing and organization: an overview and introduction to the special issue. Organization Studies, 32(9), 1149-1170. http://dx.doi.org/10.1177/0170840611410836

Courpasson, D., Dany, F., \& Martí, I. (2016). Organizational entrepreneusshio as active resistance: a struggle against outsourcing. Entrepreneurship Theory and Practice, 40(1), 131-160. http://dx.doi.org/10.1111/etap.12109

Deleuze, G. (2005). Foucault. São Paulo: Brasiliense.

Dendle, P. (2011). Cryptozoology and the paranormal in Harry Potter: truth and belief at the borders of consensus. Children's Literature Association Quarterly, 36(4), 410-425. http://dx.doi.org/10.1353/chq.2011.0048

Dias, L. F. F. (2016). Epistemologia barroca de triste figura: Dom Quixote como exemplo da transformação da epistèmê do século XVII a partir de As Palavras e as Coisas de Foucault. Ideias, 7(1), 271-292. 
Duarte, M. F., \& Alcadipani, R. (2016). Contribuições do organizar (organizing) para os estudos organizacionais. Organização \& Sociedade, 23(76), 57-72. http://dx.doi.org/10.1590/19849230763

Elo, S., Kääriäinen, M., Kanste, O., Pölkki, T., Utriainen, K., \& Kyngäs, H. (2014). Qualitative content analysis: a focus on trustworthiness. SAGE Publications in SAGE Open, 4, 1-10. http://dx.doi.org/10.1177/2158244014522633

Feltham-King, T., \& Macleod, C. (2016). How content analysis may complement and extend the insights of discourse analysis: an example of research on constructions of abortion in South African Newspapers 1978-2005 [Special Issue]. International Journal of Qualitative Methods, 1-9. http://dx.doi.org/10.1177/1609406915624575

Flick, U. (2009). Introdução à pesquisa qualitativa. Porto Alegre: Bookman/Artmed.

Fontenelle, I. A. (2015). Organisations as producers of consumers. Organization, 22(5), 644-660. http://dx.doi.org/10.1177/1350508415585029

Foucault, M. (2008). Nascimento da biopolítica: curso dado no Còllege de France (1978-1979). São Paulo: Martins Fontes.

Foucault, M. (2012). A arqueologia do saber. Rio de Janeiro: Forense Universitária.

Foucault, M. (2013). Ditos e escritos, volume IX: genealogia da ética, subjetividade e sexualidade. São Paulo: Forense Universitária.

Foucault, M. (2014). Microfísica do poder. Rio de Janeiro: Editora Paz e Terra.

Foucault, M. (2015). Vigiar e punir: nascimento da prisão. Petrópolis: Vozes.

Foucault, M., \& Deleuze, G. (1977). Intellectuals and power. In D. F. Bouchard (Ed.), Language, counter-memory, practice (pp. 205-217). Ithaca: Cornell University Press.

Geppert, M., Becker-Ritterspach, F., \& Mudambi, R. (2016). Politics and power in multinational companies: integrating the international business and organization studies perspectives. Organization Studies, 37(9), 1209-1225. http://dx.doi.org/10.1177/0170840616656152

Greckhamer, T., \& Cilesiz, S. (2014). Rigor, transparency, evidence, and representation in discourse analysis: challenges and recommendations. International Journal of Qualitative Methods, 13(1), 422-443. http://dx.doi.org/10.1177/160940691401300123

Guilherme, L. (2012, $1^{\circ}$ julho). Pottermore e o direito de escolha (N. Silva, Colunista). Recuperado em 7 outubro, 2014, de http://potterish.com/2012/07/pottermore-e-o-direito-de-escolha/

Guschwan, M. (2012). Fandom, brandom and the limits of participatory culture. Journal of Consumer Culture, 12(1), 19-40. http://dx.doi.org/10.1177/1469540512438154

Hall, C. (2016). 'Reading and [w]rocking': morality and musical creativity in the Harry Potter fandom. The Journal of Fandom Studies, 4(2), 193-208. http://dx.doi.org/10.1386/jfs.4.2.193_1

Hardt, C., \& Thomas, R. (2014). Discourse in a material world. Journal of Management Studies, 52(5), 680-696. http://dx.doi.org/10.1111/joms. 12113

Hoedemaekers, C. (2016). "Work hard, play hard": Fantasies of nihilism and hedonism between work and consumption. Ephemera: Theory \& Politics in Organization, 16(3), 61-94.

Holanda, L. A. (2010, maio). Resistência ao management em organizações da cultura popular. Anais do Encontro Nacional de Estudos Organizacionais, Florianópolis, SC, Brasil, 6. 
Jenkins, H. (2009). Cultura da convergência: a colisão entre os velhos e os novos meios de comunicação. São Paulo: Ed. Aleph.

Jones, C., Svejenova, Pedersen, J. S., \& Townley, B. (2016). Misfits, mavericks and mainstreams: drivers of innovation in the creative industries. Organization Studies, 37(6), 751-768. http://dx.doi.org/10.1177/0170840616647671

Korobkova, K. A., \& Black, R. W. (2014). Contrasting visions: identity, literacy, and boundary work in a fan community. E-Learning and Digital Media, 11(6), 619-632. http://dx.doi.org/10.2304/elea.2014.11.6.619

Leão, A. L. M. S., Mello, S. C. B., \& Vieira, R. S. G. (2009). O papel da teoria no método de pesquisa em Administração. Organizações em Contexto, 5(10), 1-16. http://dx.doi.org/10.15603/19828756

Marshak, R. J., \& Grant, D. (2008). Organizational discourse and new organization development practices. British Journal of Management, 19(1), S7-S19. http://dx.doi.org/10.1111/j.14678551.2008.00567

Matias, A. P., Silveira, R. B., \& Brandão, M. M. (2015). Envolvimento do consumidor no processo de desenvolvimento de produtos como medida de sucesso: um estudo com empresas participantes dos prêmios FINEP e Nacional de Inovação. Revista de Administração e Inovação, 12(1), 174200. http://dx.doi.org/10.11606/rai.v12i1.100321

McCorkindale, T., DiStaso, M. W., \& Sisco, H. F. (2013). How millennials are engaging and building relationships with organizations on facebook. The Journal of Social Media in Society, 2(1), 6687.

Moura, D. C. (2013). Abordagens no campo da comunicação e o desafio contemporâneo da mobilidade: jovens e o smartphone. Razón y Palabra, 18(84), 1-13.

Morse, J. M., Barrett, M., Mayan, M., Olson, K., \& Spiers, J. (2002). Verification strategies for establishing reliability and validity in qualitative research. International Journal of Qualitative Methods, l(2), 13-22. http://dx.doi.org/10.1177/160940690200100202

Myers, K. K., \& Sadaghiani, K. (2010). Millennials in the workplace: a communication perspective on millennials organizational relationships and performance [Eletronic Version]. Journal of Business and Psychology, 25(2), 225-238. Retrieved from http://link.springer.com/article/10.1007/s10869010-9172-7. http://dx.doi.org/10.1007/s10869-010-9172-7

Oliveira, J. S., \& Cavedon, N. R. (2013). Micropolíticas das práticas cotidianas: etnografando uma organização circense. Revista de Administração de Empresas, 53(2), 156-168. http://dx.doi.org/10.1590/S0034-75902013000200004

Paiva, F. G., Jr., Leão, A. L. M. de S., \& Mello, S. C. B. de (2011). Validade e confiabilidade na pesquisa qualitativa em Administração. Revista de Ciências da Administração, 13(31), 190-209. http://dx.doi.org/10.5007/2175-8077.2011v13n31p190

Pearson, R. (2010). Fandom in the digital era. Popular Communication: The International Journal of Media and Culture, 8(1), 84-95. http://dx.doi.org/10.1080/15405700903502346

Raffnsøe, S., Gudmand-Høyer, M., \& Thaning, M. S. (2016). Foucault's dispositive: the perspicacity of dispositive analytics in organizational research. Organization, 23(2), 272-298. http://dx.doi.org/10.1177/1350508414549885

Redd, D. S. (2016). Work without labor: consumption and the imagination of work futures in India. Ephemera: Theory \& Politics in Organization, 16(3), 21-35. 
Redden, J., \& Steiner, C. J. (2000). Fanatical consumers: towards a framework for research. Journal of Consumer Marketing, 17(4), 322-337. http://dx.doi.org/10.1108/07363760010335349

Rodgers, D. M., Petersen, J., \& Sanderson, J. (2016). Commemorating alternative organizations and marginalized spaces: the case of forgotten Finntowns. Organization, 23(1), 90-113. http://dx.doi.org/10.1177/1350508415605110

Rosenberg, A. (2015, January 13). How 'Harry Potter' fans won a four-year fight against child slavery. Retrieved from http://www.washingtonpost.com/news/act-four/wp/2015/01/13/how-harrypotter-fans-won-a-four-year-fight-against-child-slavery/

Sampaio, I. C., Fortunato, G., \& Bastos, S. A. P. (2013). A estratégia como prática social: o pensar e o agir em um programa social governamental. Organização \& Sociedade, 20(66), 479-499. http://dx.doi.org/10.1590/S1984-92302013000300007

Sewell, H. L. (n.d.). Potter war. Retrieved from http://www.heathershow.com/potterwar/

Souza, E. M. (2012). Pós-modernidade nos estudos organizacionais: equívocos, antagonismos e dilemas. Cadernos Ebape.BR, 10(2), 270-283. http://dx.doi.org/10.1590/S1679-39512012000200003

Souza, E. M., Bianco, M. F., \& Machado, L. D. (2005, setembro). As discursividades organizacionais sob a ótica foucaultiana. Anais do Encontro Nacional da Associação Nacional de Pós-Graduação e Pesquisa em Administração, Brasília, DF, Brasil, 29.

Souza, E. M., Junquilho, G. S., Machado, L. D., \& Bianco, M. F. (2006). A analítica de Foucault e suas implicações nos estudos organizacionais sobre o poder. Organizações \& Sociedade, 13(36),1225. http://dx.doi.org/10.1590/S1984-92302006000100001

Souza, E. M., Bianco, M. F., \& Silva, P. O. M. (2016). Análise arqueológica das estratégias utilizadas por homossexuais no trabalho bancário. Farol - Revistas de Estudos Organizacionais e Sociedade, 3(6), 12-59.

Souza, E. M., Petinelli-Souza, S., \& Silva, A. R. L. (2013). O pós-estruturalismo e os estudos críticos de gestão: da busca pela emancipação à constituição do sujeito. Revista de Administração Contemporânea, 17, 198-217. http://dx.doi.org/10.1590/S1415-65552013000200005

Thomas, R., Sargent, L., \& Hardy, C. (2011). Managing change: negotiating meaning and power$\begin{array}{llll}\text { resistance } & \text { relations. } & \text { Organization } & \text { Science, }\end{array}$ http://dx.doi.org/10.1287/orsc.1090.0520

Thorne, S., \& Bruner, G. C. (2006). An exploratory investigation of the characteristics of consumer fanaticism. Qualitative Market Research, 9(1), 51-72. http://dx.doi.org/10.1108/13522750610640558

Välikangas, A., \& Seeck, H. (2011). Exploring the foucauldian interpretation of power and subject in organizations. Journal of Management \& Organization, 17(6), 812-827. http://dx.doi.org/10.1017/S183336720000119X

\section{Dados dos Autores}

